\title{
Pengaruh Aplikasi Zoom Kuliah Daring Terhadap Minat Belajar Mahasiswa Program Studi Manajemen Fakultas Ekonomi - UMRAH pada Masa Pandemi Covid 19
}

\author{
Akhirman \\ Dosen Jurusan Manajemen, Fakultas Ekonomi Univeristas Maritim Raja Ali Haji \\ Tanjugpinang, Indonesia
}

\begin{abstract}
ABSTRAK : Wabah Virus Corona Covid'19 telah merubah tatatan kehidupan masyarakat seluruh bangsa disegala penjuru. Termasuk salah satunya Indonesia. Penelitian ini khusus ditujukan pada aktivitas bidang pendidikan selama Covid'19, dengan judul "Pengaruh Aplikasi Zoom Kuliah Daring Terhadap Minat Belajar Mahasiswa Program Studi Manajemen Fakultas Ekonomi - UMRAH Pada Masa Pandemi Covid'19". Peneltian dengan kesimpulan bahwa. Sebanyak 119 responden atau 55\% responden menyatakan bahwa Perkuliahan daring menggunakan aplikasi Zoom, sebagai perkuliahan yang Lebih nyaman dalam berdiskusi dan tanya jawab antar mahasiswa dan dosen. Yang kedua sebanyak ada 118 responden atau 54,4\%, mahasiwa pada umumnya memiliki perangkat/peralatan untuk mengikuti kuliah dari rumah sesuai dengan petunjuk yang diberikan, dan yang ke Tiga adalah untuk menggunakan aplikasi Zoom, sebanyak 115 atau $53 \%$ responden menyatakan bahwa dosen selama kuliah daring, memberikan respon terhadap pertanyaan yang muncul selama kuliah daring dan dosen memiliki Kompetensi yang baik.
\end{abstract}

Kata Kunci : Pengaruh Aplikasi Zoom, Kuliah Daring, Minat Belajar Mahasiswa.

\section{Email Addres : akhirman@umrah.ac.id}

\section{Pendahuluan}

Kuliah merupakan sebutan untuk proses belajar pada tingkat mahasiswa yaitu proses seseorang untuk dapat mengetahui, memahami dan melakukan dari hal yang tadinya belum diketahui, dipahami dan tidak dapat dilakukan menjadi mudah dan dapat dipahami. Proses belajar yang kurang maksimal dapat menyebabkan hasil belajar yang kurang maksimal. Nana Sudjana dalam (Widyaningrum and Murwanintyas, 2012) mengatakan hasil belajar adalah kemampuan-kemampuan yang dimiliki siswa setelah ia menerima pengalaman belajarnya. Pengalaman belajar siswa diperoleh dari proses belajar siswa, maka proses belajar siswa dapat mempengaruhi hasil belajar siswa.

Sejak Wabah pandemi akibat penyebaran virus Corona (Covid-19) telah menyebabkan beragam kepanikan, salah satunya di ranah pendidikan tinggi. Kampus harus merumahkan dosen, tendik, dan mahasiswa. Kuliah yang normalnya lebih banyak dilakukan dengan tatap muka di kelas harus berubah format menjadi perkuliahan daring (online). 
Sebagaimana Negara lain, Indonesia juga membuat kebijakan meliburkan seluruh lembaga Pendidikan untuk beraktifitas di kelas bersama secara offline. Akan tetapi seluruh perguruan tinggi diminta menerapkan teknologi pembelajarn untuk perkuliahan via online. Hal ini bertujuan sebagai upaya mencegah penularan COVID-19. Hal ini bukan menjadi sebuah masalah bagi beberapa perguruan tinggi yang memiliki sistem akademik berbasis daring. Namun akan menjadi masalah bagi perguruan tinggi yang belum memiliki akademik berbasis daring. Kuliah dengan sistem online bertujuan memberikan kesempatan kepada seluruh warga Negara Indonesia untuk dapat menikmati proses pembelajaran dimana saja berada. Hal ini pernah diprediksikan oleh Thomas L.

Friedman bahwa kedepan perkuliahan mahasiswa cukup duduk di depan komputer yang tersambung dengan jaringan internet dimana saja, sudah bisa melakukan proses perkuliahan walaupun tidak menyatakan secara spesifik akibat COVID-19

Sistem Pembelajaran Daring Indonesia (SPADA) Indonesia. PDITT/SPADA telah diluncurkan oleh Wakil Presiden RI pda tanggal 15 Oktober 2014. Tujuan utama SPADA adalah menerapkan teknologi pendidikan, khususnya blended learning sebagai wahana alih kredit (credit transfer) untuk memecahkan salah satu tantangan pendidikan tinggi dewasa ini yaitu meningkatkan akses terhadap pendidikan tinggi yang bermutu. Melalui SPADA saat ini dosen harus menyampaikan materi kuliah beserta evaluasi pembelajaran menggunakan Sistem Pembelajaran Daring, demikian juga sebaliknya mahasiswa harus mengikuti Sistem Pembelajaran Daring seperti yang berjalan sekarang ini.
Walapun SPADA (Sistem Pembelajaran Daring) Indonesia, sudah lama dikenal namun berdasarkan hasil penelitian ini masih terdapat banyak hal yang harus dipahami, dan disempurnakan seperti kemampuan SDM dosen menggunakan berbagai metode kuliah daring, peralatan elektronik penunjang pembelajaran, materi yang harus telah disiapkan. Demikian juga dengan mahassiwa masih terdapat banyak kelemahan seperti ruang untuk dijadikan tempat kuliah daring jauh dari gangguan kebisingan lingkungan, perangkat elektronik yang harus memadai seperti Lap Top dan sejenisnya, keterjangkauan internet pada berbagai wilayah dimana mahasiswa tinggal saat kuliah daring, biaya yang cukup untuk pembelian paket yang akan digunakan. ,

Kuliah daring merupakan cara baru dosen dan mahasiswa pada proses kuliah sejak wabah pandemi covid'19 ini. Tentu banyak hal yang diyakini perkuliahan berdampak pada minat mahasiswa yang akan mengikuti perkuliahan karena beberapa hal berikut seperti; Proses, Kompetensi, Sarana dan Prasarana.

Menurut Djaali (2007), "minat adalah rasa lebih suka dan rasa keterikatan pada sesuatu hal atau aktivitas tanpa ada yang menyuruh". Hal senada diungkapkan pula oleh Slameto (2010) bahwa, "minat sebagai kecenderungan yang tetap untuk memperhatikan terus-menerus yang disertai rasa senang”. Dari pernyataan tersebut mengindikasikan bahwa minat dicirikan dengan rasa lebih suka, rasa tertarik atau rasa senang sebagai bentuk ekspresi terhadap sesuatu hal yang diminati.

\section{Metodologi Penelitian}

\begin{tabular}{lrrr}
\multicolumn{2}{c}{ Metode penelitian } & \multicolumn{2}{r}{ menggunakan } \\
penelitian mixed methods, yang & pertama \\
melakukan analisa kan analisa & statistik \\
& & 104
\end{tabular}


parametris dan non parametris dari data kuantitatif bedasarkan data statistik hasil pengolahan data yang diberikan, kemudian melakukan deskriptif kualitatif dengan menggambarkan dampak kuliah online kepada para mahasiswa. Melalui pertanyaan terkait proses perkuliahan, kompetensi dosen, sarana dan prasarana yang digunakan yang dapat membangun minat mahasiswa mengiktui kuliah walaupun dengan jarak yang berbeda. Penelitian dilakukan dengan teknik pengumpulan data melalui pengisian kuesioner yang di berikan kepada mahasiswa. Sampel pada penelitian ini adalah mahasiswa Semester IV dan VI dari 6 Kelas dengan jumlah keseluruhan 217 orang. Kemudian dilakukan analisis data, penyajian data, dan kesimpulan. Teknik pengumpulan data lewat survey, merupakan penelitian yang sumber data dan informasi utamanya diperoleh dari responden sebagai sampel penelitian dengan menggunakan kuesioner sebagai instrumen pengumpulan data, kuesioner dari google form. Kuesioner yang terkumpul di olah dengan menggunakan Software Excel untuk mendapatkan data berupa tampilan grafik, sehingga dari data penelitian ini dapat dieksplorasi untuk dibuatkan deskripsinya dampak kuliah online dihubungkan dengan minat mahasiswa dalam mengikuti perkuliahan dengan karena proses, kompetensi, sarana dan prasarana yang dimiliki. Kemudian di carikan penguatan melalui referensi yang didapat dari penelitian

\section{Pengolahan Data}

Pengolahan data menggunakan engolahan Data menggunakan Software Excel. Excel merupakan salah satu produk Microsoft 2016 yang berupa lembar kerja dalam bentuk spreadsheet. Pada umumnya Microsoft excel digunakan untuk membantu user dalam mengolah data. Adapun data kuesioner ini bersumber dari mahasiswa Telkom University sebanyak 217 responden dan nilai prosentanse pada grafik dilakukan pembulatan sesuai standar tetapi hasil akhir di data primer tetap $100 \%$.

\section{Data Hasil pengolahan}

Hasil dari pengolahan data menggunakan excel dari jawaban - jawaban para mahasiswa, sesuai pertanyaan-pertanyaan yang dibuat dalam bentuk tabel, kemudian di olah dengan exel, dan akan di tampilkan dalam bentuk grafik, yang bisa dilihat pada gambar dibawah ini. Sebagai informasi untuk analisa dari hasil pengolahan data hasil jawaban responden.

Tabel 1.

Deskripsi responden

\begin{tabular}{|l|c|c|c|c|c|c|c|}
\hline \multicolumn{7}{|c|}{ Jumlah responden } \\
\hline Kelas & A-3 & A-4 & A-6 & A-9 & $\begin{array}{l}\text { A- } \\
11\end{array}$ & $\begin{array}{l}\text { A- } \\
12\end{array}$ & Total \\
\cline { 2 - 8 } & 43 & 41 & 21 & 28 & 41 & 43 & 217 \\
& $(\%)$ & $(\%)$ & $(\%)$ & $(\%)$ & $(\%)$ & $(\%)$ & $(\%)$ \\
& $(20)$ & $(19)$ & $(10)$ & $(13)$ & $(19)$ & $(20)$ & $(100)$ \\
\hline Jenis & \multicolumn{3}{|c|}{ Laki-laki } & \multicolumn{3}{c|}{ Perempuan } & Total \\
Kela & \multicolumn{3}{|c|}{$(\%)$} & \multicolumn{3}{c}{$(\%)$} & $(\%)$ \\
min & \multicolumn{3}{|c|}{120} & \multicolumn{3}{c}{97} & 217 \\
& \multicolumn{3}{|c|}{$(55)$} & \multicolumn{3}{c}{$(45)$} & $(100)$ \\
\hline
\end{tabular}

Sumber : Data olahan (2020).

Dari data di atas dapat diketahui bahwa total keseluruhan mahasiswa dari 6 kelas tersebut berjumlah 217 orang, mahasiswa berjenis kelami laki-laki berjumlah 120 orang atau 55 persen, selebihnya adalah perempuan berjumlah 97 orang atau 45 persen.

\section{Hasil dan Pembahasan}


Tabel 2.

Hasil Pengisian Kuesioner oleh Responden

\begin{tabular}{|c|c|c|c|c|c|c|c|c|c|c|c|}
\hline No & Item & & TS & & & & $3 S$ & & S & & \\
\hline $\mathbf{A}$ & Prose belajar mengajar. & $\mathrm{f}$ & $\%$ & $\mathrm{~F}$ & $\%$ & $\mathrm{~F}$ & $\%$ & $\mathrm{f}$ & $\%$ & $\mathrm{f}$ & $\%$ \\
\hline 1 & $\begin{array}{l}\text { Pelaksanaan Perkuliahan daring dapat diakses secara } \\
\text { mudah }\end{array}$ & 2 & 0,9 & 3 & 1,4 & 38 & 17,5 & 102 & 47,0 & 72 & 33,2 \\
\hline 2 & $\begin{array}{l}\text { Pelaksanaan Perkuliahan daring tepat waktu dan } \\
\text { sesuai dengan jadwal }\end{array}$ & 4 & 1,8 & 6 & 2,8 & 36 & 16,6 & 98 & 45,2 & 73 & 33,6 \\
\hline 3 & $\begin{array}{l}\text { Perkuliahan secara daring menambah pemahaman } \\
\text { teori dan keterampilan }\end{array}$ & 1 & 0,5 & 3 & 1,4 & 37 & 17,0 & 110 & 50,7 & 66 & 30,4 \\
\hline 4 & $\begin{array}{l}\text { Materi yang disajikan secara daring sesuai dengan } \\
\text { Kontrak Perkuliahan/RPS }\end{array}$ & 3 & 1,4 & 7 & 3,2 & 42 & 19,3 & 97 & 44,7 & 68 & 31,3 \\
\hline 5 & $\begin{array}{l}\text { Kemudahan untuk saling mengetahui satu sama } \\
\text { lainnya }\end{array}$ & 2 & 0,9 & 3 & 1,4 & 32 & 14,7 & 112 & 51,6 & 68 & 31,3 \\
\hline 6 & $\begin{array}{l}\text { Lebih nyaman dalam berdiskusi dan Tanya jawab } \\
\text { antar mahasiswa dan dosen. }\end{array}$ & 3 & 1,4 & 8 & 3,7 & 22 & 10,1 & 119 & 54,9 & 65 & 30,0 \\
\hline B & Kompetensi Dosen & & & & & & & & & & \\
\hline 1 & $\begin{array}{l}\text { Dosen setia selama prose belajar, mengajar. secara } \\
\text { daring hingga selesai }\end{array}$ & 2 & 0,9 & 6 & 2,8 & 20 & 9,2 & 32 & 14,7 & 157 & 72,3 \\
\hline 2 & $\begin{array}{l}\text { Dosen menjelaskan arah dan tujuan dalam setiap } \\
\text { pembelajaran secara daring }\end{array}$ & 4 & 1,8 & 5 & 2,3 & 41 & 19,9 & 109 & 50,2 & 98 & 45,2 \\
\hline 3 & $\begin{array}{l}\text { Dosen memberikan kesempatan mahasiswa untuk } \\
\text { bertanya dan berdiskusi }\end{array}$ & 3 & 1,4 & 7 & 3,2 & 44 & 20,3 & 112 & 51,6 & 51 & 23,5 \\
\hline 4 & $\begin{array}{l}\text { Dosen memberikan respon terhadap pertanyaan yang } \\
\text { muncul selama perkuliahan secara daring }\end{array}$ & 4 & 1,8 & 7 & 3,2 & 40 & 18,4 & 115 & 53,0 & 51 & 23,5 \\
\hline 5 & $\begin{array}{l}\text { Tingkat pemahaman anda secara umum terhadap } \\
\text { mata kuliah yang disajikan secara daring }\end{array}$ & 3 & 1.4 & 6 & 2,8 & 39 & 18,0 & 109 & 50,23 & 60 & 27,6 \\
\hline 6 & $\begin{array}{l}\text { Rerata keaktifan dan attitude anda selama } \\
\text { perkuliahan secara daring }\end{array}$ & 3 & 1,4 & 7 & 3.2 & 41 & 18,9 & 112 & 51,6 & 54 & 24,9 \\
\hline $\mathbf{C}$ & Sarana dan Prasarana & & & & & & & & & & \\
\hline 1 & $\begin{array}{l}\text { Materi pada pembelajaran selalu dibagikan lebih } \\
\text { awal dan ada juga powerpoint. }\end{array}$ & 4 & 1,8 & 9 & 4,1 & 52 & 24,0 & 96 & 44,2 & 56 & 25,8 \\
\hline 2 & $\begin{array}{l}\text { Saya memiliki perangkat/peralatan untuk mengikuti } \\
\text { kuliah dari rumah sesuai dengan petunjuk yang } \\
\text { diberikan }\end{array}$ & 2 & 0,9 & 5 & 2,4 & 54 & 24,9 & 118 & 54,4 & 38 & 17,5 \\
\hline 3 & $\begin{array}{l}\text { Tidak keberatan dengan biaya untuk mengikuti } \\
\text { perkuliahan }\end{array}$ & 7 & 3,2 & 12 & 5,5 & 76 & 35,0 & 103 & 47,5 & 19 & 8,7 \\
\hline
\end{tabular}

Sumber : Data di olah (2020)

A. Proses belajar mengajar.

Pengolahan hasil data tabel.

\section{Aspek Proses Perkuliahan}

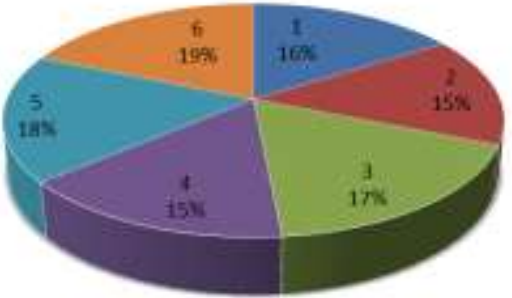




\section{Deskripsi Hasil Penelitian.}

A. Pertanyaan Untuk aspek Prose belajar mengajar mengajar ada 6 pertanyaan, dan 217 responden menyatakan bahwa:

1. Reponden memilih proses belajar mengajar lebih nyaman dalam berdiskusi dan tanya jawab antar sesama mahasiswa dan dosen, sebagai peringkat pertama yaitu 119 respndon atau sebanyak $19 \%$.

2. Pernyataan saling mengetahui satu sama lainnya sebanyak 112 responden atau $18 \%$.

3. Pernyataan kuliah daring menambah pengalaman dan keterampilan dijawab oleh 110 responden atau $17 \%$.

4. Perkuliahan secara daring dapat di akses secara mudah dijawab oleh 102 responden atau $16 \%$.

5. Peringkat ke 5 adalah pelaksanaan kuliah daring dilaksanakan tepat waktu dengan jumlah jawaban 98 responden atau $15 \%$ dan

6. Peringkat ke 6 untuk pertanyaan Materi yang disajikan secara daring sesuai dengan Kontrak Perkuliahan/RPS berjumlah 97 responden atau $15 \%$

B. Pertanyaan Untuk aspek Kompetensi Dosen, dengan 6 pertanyaan, 217 respondan, hasil sebagai berikut.

\section{Aspek Kompetensi Dosen}

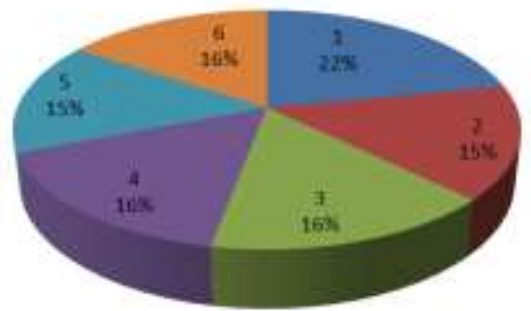

Adapun tanggapan responden terhada Kompetensi Dosen selma Kuliah Daring adalah sebaga beriku.

1. Ada 157 ata $22 \%$ Responden menjawab bahw dosen setia selama proes belajar, mengaar secara darig mendamping mahasiswa.

2. Selanjtunya sebanyak 115 responden atau $16 \%$ responde meberikan respon terhadap pertanyaan yang muncul selama perkulihan secara daring.

3. Posis ke tigas bahwa ada 112 responden atau $16 \%$ responden menyatakan bahwa dosen memberikan kesepatan mahasiswa untuk bertaya dn berdiskusi.

4. Selanjutnya ada 112 responden atau $16 \%$ menyatakan kuliah daring memberikan pemahaman dan pengalama baru.

5. Sebanyak 109 atau $15 \%$ dari responen menyatakan bahwa dosen menjelaskan arah dan tujuan dalam setia pemelajaran secara daing.

6. 109 Respon memilih rerata keaktifan dan attitude peserta selama perkuliaha daring

\section{Aspek Sarana dan Prasarana.}

Aspek sarana dan prasarana terdiri dari 3 pertanyaan, akan di respon oleh 217 responden. 


\section{Aspek Sarana dan Prasarana}

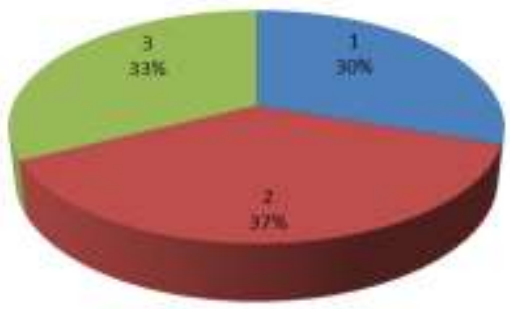

Dari gambar tersebut dapat diktahui bahwa :

1. Ada $37 \%$ atau 118 responden mmberikn respon tertinggi pada pertanyaan bahwa mahasiswa memiliki perangkat/peralatan untuk mengikuti kuliah dari rumah sesuai dengan petunjuk yang diberikan;

2. Sebanyak $33 \%$ atau 103 responden memberikan respon terbanyak kedua terkait pertanyaan bahwa, mahasiswa tidak keberatan dengan biaya untuk mengikuti perkuliahan daring, kemungkinan mereka memiliki link internet di rumah atau ditempat lainnya.

3. Semengara untuk pertanyaan nomo 1 responden memberikan tanggapan sebanyak $30 \%$ atau 96 responden menyatakan bahwa, Materi pembelajaran selalu dibagikan lebih awal sebelum perkuliahan.

\section{Kesimpulan}

Hasil dari penelitian ditemukan hubungan yang erat antara perkuliahan daring dengan minat mahasiswa mengikuti perkuliahan. Dari 3 Aspek dan 15 pertanyaan yang di ajukan, dapat disimpulkan dan dapat dilihat pada gambar berikut ini.

\section{Tiga aspek penting dari Aplikasi Zoom}

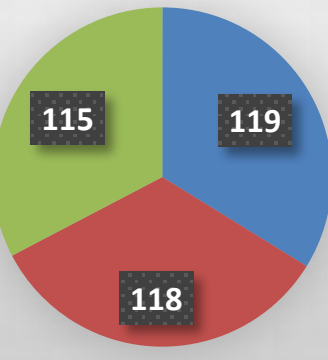

Sumber: Data di olah (2020)

Keterangan :

1. Pertanyaan terkait Aspek Proses, yaitu point ke 6 sebanyak 119 responden atau 55\% responden menjawab bahwa Perkuliahan daring menggunakan aplikasi Zoom, sebagai perkuliahan daring yang Lebih nyaman dalam berdiskusi dan tanya jawab antar mahasiswa dan dosen,

2. Pilihan Aspek Sarana dan Prasarana, yaitu point ke 2, bahwa ada 118 responden atau $54,4 \%$, mahasiwa pada umumnya memiliki perangkat/peralatan untuk mengikuti kuliah dari rumah sesuai dengan petunjuk yang diberikan;

3. Sementara posisi ke tiga adalah terkait pertanyaan Aspek Kompetensi, sebanyak 115 atau $53 \%$ responden menyatakan bahwa dosen selama kuliah daring, memberikan respon terhadap pertanyaan yang muncul selama kuliah daring.

\section{Daftar Pustaka}

Widyaningrum, Yulia Tri, and Ch Enny Murwanintyas. (2012). "Pengaruh Media

Pembelajaran Geogebra Terhadap Grafik Fungsi Kuadrat Di Kelas X SMA 
Jurnal Bahtera Inovasi Vol. 3 No. 2 Tahun 2020

@ Program Studi Manajemen

FE Universitas Maritim Raja Ali Haji

Negeri 2 Yogyakarta Tahun Pelajaran 2012/2013.” In Prosiding Seminar Nasional Matematika dan Pendidikan Matematika FMIPA UNY, 975-980. Yogyakarta

Thomas L. Friedman | The New York Times Published: June 17Updated: June 18, 2020

Slameto. 2010. Belajar dan Faktor yang mempengaruhinya. Jakarta: Rineka Cipta.

Djaali. 2007. Psikologi Pendidikan. Jakarta: Bumi Aksara 